\title{
Rough Set Method for Determining Knowledge Attribute on Customer Satisfaction
}

Submitted 18/11/20, $1^{\text {st }}$ revision 25/01/21, $2^{\text {nd }}$ revision 28/02/21, accepted 20/03/21

\author{
Nanik Istianingsih ${ }^{1}$, Sarjon Defit ${ }^{2}$
}

\begin{abstract}
:
Purpose: The research aims to determine how the level of customer satisfaction in a small business is a field of flower arrangement services as well as information that can dug from a collection of customer data.

Approach/Methodology/Design: The samples used were ten customers who considered loyal. The method used is a Rough set with a satisfaction attribute consisting of confidence, integrity, pride, and desire.

Findings: Based on this decision rule, confidence becomes the most dominant attribute. The results showed that the four dimensions of the emotional bond used as an attribute in the Rough Set process to analyze the level of customer satisfaction that strongly affects is the dimension of Confidence, this is evident from the resulting General Rule. Every decision produced always uses the confidence dimension in the comparison input, meaning the level of customer confidence in the company should be a special concern. In the dimensions of the emotional bonds the first dimensions are constructed and fundamental is the confidence dimension, this dimension indicates the level of customer confidence in the company. Confidence dimensions cannot stand it self yet to build long-term relationships with customers without by other dimensions.

Practical Implications: The study will contribute positively to give some information of knowledge that contained on customer satisfaction. It shown the alternative for measuring for satisfaction that can be used for a small business and academic.

Originality/Value The results generated in this study opened new avenues for customer satisfaction analysis. We must not limit the analysis of customer satisfaction survey data using conventional statistical methods. The Rough theory Set is an innovative tool for finding Knowledge of customer behaviour patterns.
\end{abstract}

Keywords: Customer satisfaction, Rough set, data mining, confidence, attribute.

JEL classification: $M 1$.

Paper Type: Article Research.

\footnotetext{
${ }^{1}$ Management Doctoral Program, Putra Indonesia University YPTK Padang, Indonesia, e-mail: nanikistianingsih1324@gmail.com

${ }^{2}$ Lecturer of Management Doctoral Program, Putra Indonesia University YPTK Padang, Indonesia, e-mail: sarjond@yahoo.co.uk
} 


\section{Introduction}

The quality of customer service should get special attention so that the company can continue to maintain the image in the customer's eyes. By prioritizing good service, customers will make it easy for the company to achieve the maximum profit by increasing the number of customers who stay continuously. An increase in the number of customers who stay this can happen if customers are satisfied with the service facilities offered by the company. Services that do not meet the quality will be very easily abandon and eventually the customer will switch to another company (Yakut, Turkoglu, and Yakut, 2015; Dhandayudam and Krishnamurthi, 2013; Salajegheh, 2016; Li, Tang, Luo, and Xu, 2009).

The purpose of analyse customer satisfaction surveys is not only to understand performance about each attribute regarding the product, the service, overall, but also to capture causal relationships between performance impacts on overall satisfaction attributes and customer loyalty. Question about the cause-dependency effect between the performance and overall attributes. The current problem encountered from the complete text archive of the journals available in satisfaction is a causal and associative relationship between factors factor that affects the customer's pusher in a simple and multiple way (Chen, 2009; Wang and Chou, 2013; Ali et al., 2016; Hadiansah, 2017).

Traditionally, customer satisfaction survey data was analysed using statistic method i.e., such as multivariate regression analysis. However, this technique is primarily based on a strong assumption as before the knowledge of self-reliance, a numerical scale of attributes and a uniform probability of distribution among independent attributes (Al-malaise, 2013). In general, the results of the study are unable to obtain conclusions from the survey data collected because the scale of the question or questionnaire statement is usually measured using an ordinal or nominal scale. Several statistic and intelligence methods have been applied to customer satisfaction analysis such as unified analysis of the smallest squares and partially targeted quadratic stages (Chen, 2009; Sembiring and Azhar, 2017).

In recent years, we have seen an increase of attention given to the satisfaction analysis in the literature intelligence method, where simple descriptions of how models of customer retention problems use a rough set model is given. Pawlak (1982) proposes a method using a rough classification for predictive purchase and discovery knowledge of customer behaviour patterns. The theory of Rough Set, introduced by Pawlak (1982), relates to the analysis of classification (Nafis, Makhtar, Awang, Rahman, and Deris, 2016; Zifu, Hong, and Lihua, 2015). Inappropriate, uncertain, or incomplete data by incorporating the classic set of theories. It has successfully applied for data analysis in pattern recognition and information processing, business and finance, industrial and environmental engineering, medical diagnosis and analysis of medical data, diagnosis of system errors and monitoring and intelligent control systems. This theory is very useful when this data cannot be analysed easily using 
traditional statistical methods (Nafis et al., 2016; Morcov, Pintelon and Kusters, 2020; Li et al., 2009).

The concept of Rough set is a reliable tool for conducting customer satisfaction analysis. Customers who feel dissatisfied are defined as customers who report overall satisfaction, but who hold the characteristic characteristics of the customer are not satisfied. These customers have a high tendency to switch to other competitors. With early warning signals, the percentage of business losses in the future can predicted, and the appropriate customer satisfaction measures can be taken for the unsatisfied customers to avoid the possibility of loss of business (Shyng, Wang, Tzeng, and Wu, 2007).

This encourages writers to research on the level of customer satisfaction. This research aims to analyse the customer satisfaction level of company. In measuring the level of customer satisfaction, the author uses the measuring system contained in the book Human Sigma is a qualitative measurement by using the four-dimensional emotional bonds of Confidence, Integrity, Pride, and Passion. Then these four dimensions will process using the Rough Set method. Where the Rough Set method can classify the data and is quite effective in the search knowledge. The resulting General Rule will depict which of these four dimensions most dominant affects customer satisfaction, so that the company can manage the strategy in creating customer satisfaction in the future (Stefanowski, 1998; Yakut et al., 2015; Jiang, Kwong, Law, and Ip, 2013).

Some research on the application of data mining methods and customer satisfaction that has been done by previous authors, among others, research conducted. This research uses several aspects or attributes such as teaching learning, tutoring, and consulting, research and community service, and other tasks beyond the main task as a consideration in judgment Subsequent research that utilizes the Rough Set method, which uses a variable of education, academic position and Department of office is then used to determine the desired rector candidate in accordance with the existing provisions. The results of the study show that education is a major factor in the election of foreign rector which is then supported by the academic position and structural department owned by the lecturer (Chen et al., 2020; Turčínek and Turčínkova, 2015; Dhandayudam and Krishnamurthi, 2013; Shyng et al., 2007; Suchacka and Chodak, 2017; Sembiring and Azhar, 2017; Hadiansah, 2017; Wang and Chou, 2013; Sanny, Susastra, Roberts, and Yusramdaleni, 2020).

\section{Research Method}

Data mining, also called Knowledge Discovery from Databases (KDD), is a process of discovering knowledge. This knowledge obtained automatically from information on the real world as well as large and complex data sets (Schoemaker, Day, and Rao, 2020). Data mining refers to the discovery of useful information from large datasets (Salajegheh, 2016). KDD is a data processing process that has several stages. The core stage of the KDD process is data mining (Dhandayudam and Krishnamurthi, 
2013). The main function of data mining is to extract the stored data patterns by applying various methods and algorithms (Liou and Tzeng, 2010; Sembiring and Azhar, 2017; Chen, 2009). Because data mining is a series of processes, data mining can divide into several phases. The stages are interactive where the user is directly involved or with the Knowledge Based (Schoemaker et al., 2020; Morcov et al., 2020; Liou, 2009). Figure 1 explained the stages of data mining as follows:

Figure 1. Step of data mining (Huang, Tseng, and Chen, 2016)

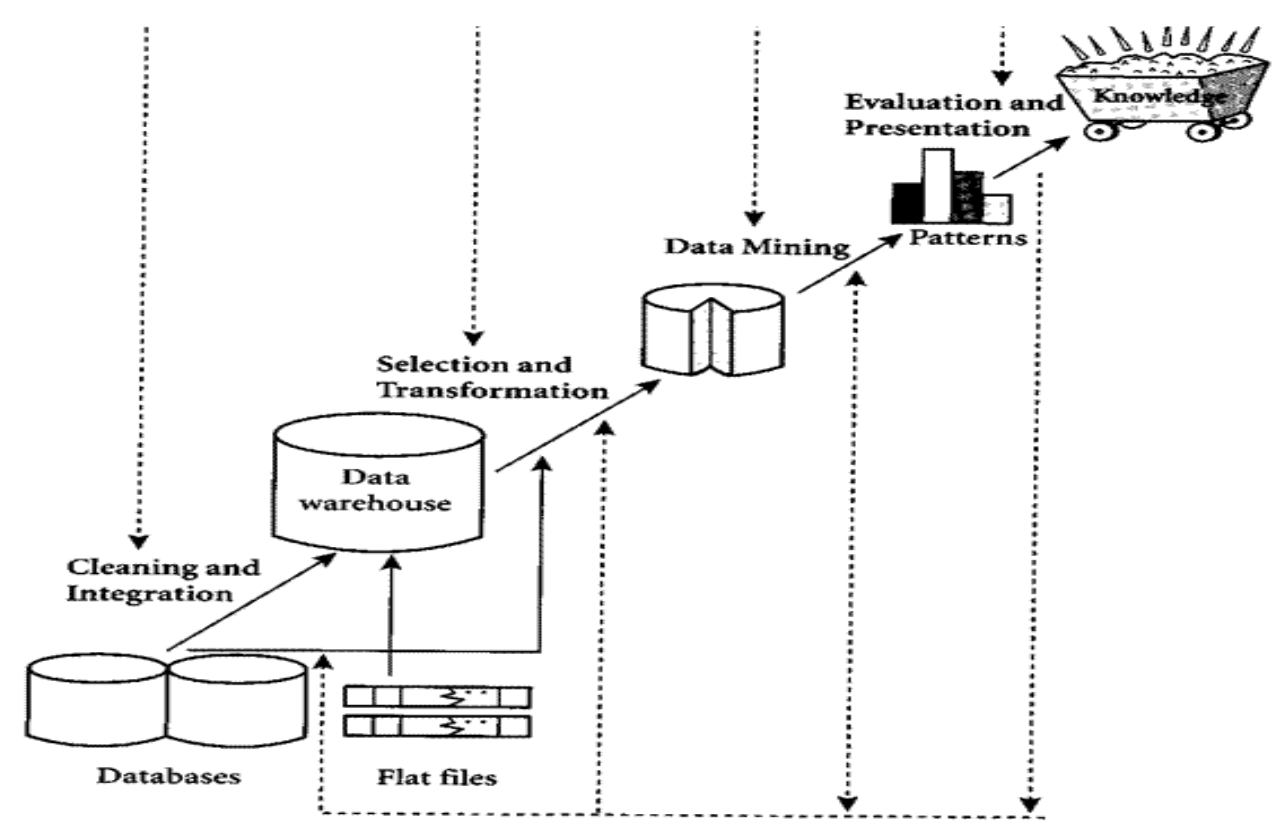

Source: Own study.

Rough Set is a part of the data mining techniques used to handle problems uncertainty, imprecision, and vagueness in Artificial intelligence (AI) applications. Rough Set is an efficient technique for KDD in the stages of process and data mining. Rough Set is a mathematical technique developed by Pawlack in the year 1980 (Chatterjee et al., 2018).

\section{Results}

Before processing the data, the first thing to do is to determine the criteria of the assessment or the output of how to be obtained, the criteria used are four-dimensional emotional bonds. Table 1 is a criterion used to determine the level of customer satisfaction.

Table 2 presents the recapitulation of the results of the quarantine of company customers that have transformed. In the Rough Set, data set is represented as a table, where the rows in the table represent objects and columns represent the attributes of those objects, the Table is called Information Systems (IS), which: 
Table 1. Valuation Criteria

\begin{tabular}{|c|c|c|c|c|c|}
\hline $\begin{array}{l}\text { Input / } \\
\text { Output }\end{array}$ & Criteria & Variable & Data Set & Score & Range \\
\hline \multirow{9}{*}{ Input } & \multirow{3}{*}{ Confidence } & \multirow{3}{*}{$\mathrm{CF}$} & Good & \multirow{3}{*}{$0-20$} & $15-20$ \\
\hline & & & Enough & & $7-14$ \\
\hline & & & Less & & $1-6$ \\
\hline & \multirow{2}{*}{ Integrity } & \multirow{2}{*}{ IG } & High & \multirow{2}{*}{$0-8$} & $6-8$ \\
\hline & & & Less & & $1-5$ \\
\hline & \multirow{2}{*}{ Pride } & \multirow{2}{*}{ PR } & High & \multirow{2}{*}{$0-8$} & $6-8$ \\
\hline & & & Less & & $1-5$ \\
\hline & \multirow{2}{*}{ Passion } & \multirow{2}{*}{ PS } & High & \multirow{2}{*}{$0-8$} & $6-8$ \\
\hline & & & Less & & $1-5$ \\
\hline \multirow{3}{*}{ Output } & \multirow{3}{*}{$\begin{array}{c}\text { Customer } \\
\text { Satisfaction }\end{array}$} & \multirow{3}{*}{$\mathrm{CS}$} & $\begin{array}{c}\text { Very } \\
\text { Satisfied }\end{array}$ & \multirow{3}{*}{$0-44$} & $34-44$ \\
\hline & & & $\begin{array}{c}\text { Quite } \\
\text { Satisfied } \\
\end{array}$ & & $16-33$ \\
\hline & & & $\begin{array}{c}\text { Not } \\
\text { Satisfied }\end{array}$ & & $1-15$ \\
\hline
\end{tabular}

Source: Own study.

Table 2. Information Systems

\begin{tabular}{ccccc}
\hline Name & Confidence & Integrity & Pride & Passion \\
\hline H. Hasim A & 15 & 6 & 6 & 6 \\
\hline Mahkota & 14 & 6 & 6 & 5 \\
\hline $\begin{array}{c}\text { Vera } \\
\text { Magria }\end{array}$ & 20 & 8 & 8 & 8 \\
\hline PT. Djarum & 15 & 6 & 6 & 6 \\
\hline Sanbe & 11 & 4 & 5 & 4 \\
Farma & & & & 4 \\
\hline PM & 10 & 5 & 5 & 6 \\
\hline Malaya & 15 & 7 & 6 & 6 \\
\hline Smansa & 14 & 6 & 7 & 7 \\
\hline Setih Setio & 16 & 6 & 6 & 6 \\
\hline Mega Bank & 16 & 6 & 6 & \\
\hline
\end{tabular}

Source: Own study.

In the use of Information Systems, there is the outcome of a known classification called the decision attribute. The Information Systems called the Decision System (DS), which described as (Table 3):

Table 3. Decision system

\begin{tabular}{|c|c|c|c|c|c|}
\hline Name & Confidence & Integrity & Pride & Passion & $\begin{array}{c}\text { Customer } \\
\text { Satisfaction }\end{array}$ \\
\hline H. Hasim A & 15 & 6 & 6 & 6 & Very Satisfied \\
\hline Mahkota & 14 & 6 & 6 & 5 & Quite Satisfied \\
\hline Vera Magria & 20 & 8 & 8 & 8 & Very Satisfied \\
\hline PT. Djarum & 15 & 6 & 6 & 6 & Very Satisfied \\
\hline Sanbe Farma & 11 & 4 & 5 & 4 & Quite Satisfied \\
\hline
\end{tabular}




\begin{tabular}{|c|c|c|c|c|c|}
\hline PM & 10 & 5 & 5 & 4 & Quite Satisfied \\
\hline Malaya & 15 & 7 & 6 & 6 & Very Satisfied \\
\hline Smansa & 14 & 6 & 7 & 6 & Very Satisfied \\
\hline Setih Setio & 16 & 6 & 6 & 7 & Very Satisfied \\
\hline Mega Bank & 16 & 6 & 6 & 6 & Very Satisfied \\
\hline
\end{tabular}

Source: Own study.

The next stage is the formation of Equivalence Class. The first step is the data in the transformation in the form attribute A (Confidence), attribute B (Integrity), attribute C (Pride) and attribute D (Passion). Each of these attributes or variables converted into the set form according to the specified range. Table 4 describes the results of the Decision System formation after second transformations.

Table 4. Second Transformations of decision System

\begin{tabular}{|c|c|c|c|c|c|}
\hline Object & Confidence & Integrity & Pride & Passion & $\begin{array}{c}\text { Customer } \\
\text { Satisfaction }\end{array}$ \\
\hline A & Good & High & High & High & Very Satisfied \\
\hline B & Enough & High & High & High & Quite Satisfied \\
\hline C & Good & High & High & High & Very Satisfied \\
\hline D & Good & High & High & High & Very Satisfied \\
\hline E & Enough & Less & High & Less & Quite Satisfied \\
\hline F & Enough & High & High & Less & Quite Satisfied \\
\hline G & Good & High & High & High & Very Satisfied \\
\hline H & Enough & High & High & High & Very Satisfied \\
\hline I & Good & High & High & High & Very Satisfied \\
\hline J & Good & High & High & High & Very Satisfied \\
\hline
\end{tabular}

Source: Own study.

Equivalence Class is the process of grouping the same objects. In Table 5 can be seen the result of forming equivalent Class, where we can obtain equivalent Class (EC1 EC4).

Table 5. Equivalent Class

\begin{tabular}{cccccc}
\hline & A & B & C & D & E \\
\hline EC1 & Enough & High & High & High & Quite Satisfied \\
\hline EC2 & Enough & High & High & Less & Quite Satisfied \\
\hline EC3 & Enough & Less & High & Less & Quite Satisfied \\
\hline EC4 & Good & High & High & High & Very Satisfied \\
\hline
\end{tabular}

Source: Own study.

The next step of forming Discernibility Matrix Modulo D. Discernibility Matrix Modulo D is a matrix that contains comparisons between different data attribute conditions and decision attributes. Data with different attribute conditions, but the same decision attribute still considered the same. To get the discernibility matrix value is to classify the different attributes between the I (line) object and the To-J 
Object (column), if the same then is given the $\mathrm{X}$ mark. As for the Discernibility Matrix Modulo D can it be seen in Table 6:

Table 6. Modulo Matrix D

\begin{tabular}{ccccc}
\hline Object & EC1 & EC2 & EC3 & EC4 \\
\hline EC1 & X & BD & D & X \\
\hline EC2 & BD & X & X & ABD \\
\hline EC3 & D & X & X & AD \\
\hline EC4 & X & ABD & AD & X \\
\hline
\end{tabular}

Source: Own study.

The next Rough Set process is a Reduction. The author uses Discernibility Matrix as a reference to perform the Reduction process. For the data that the number of variables is very large, it is not possible to search the entire combination of existing variables, therefore created a search technique attribute combination known as Quick Reduction is by: The first sought-after Indiscernibility value is Indiscernibility which the smallest attribute combination of one item; Then do the lookup process of dependency attributes if the dependency attributes value gets equal to one item then Indiscernibility for the set of minimum variables is the variable; If in the search process the attribute combination does not find the dependency attributes equal to one item, then do a greater combination search, where the combination of variable $\mathrm{s}$ sought is a combination of variables that are the greatest dependency attributes value. Perform last process until the dependency attributes value is equal to one item.

In Table 7 can be seen some Boolean theorems used in the Rough Set algorithm to produce Reduction (Acharjya and Das, 2017; Omar, Syed-abdullah, and Mohd, 2012).

Table 7. Boolean Theorems

\begin{tabular}{|l|l|r|}
\hline Boolean Theorems & Reduction & $(4)$ \\
\hline Comutative Law & $\mathrm{A}+\mathrm{B}=\mathrm{B}+\mathrm{A}$ & $(5)$ \\
& $\mathrm{A} * \mathrm{~B}=\mathrm{B} * \mathrm{~A}$ & $(6)$ \\
\hline Associative Law & $(\mathrm{A}+\mathrm{B})+\mathrm{C}=\mathrm{A}+(\mathrm{B}+\mathrm{C})$ & $(7)$ \\
\hline Distributive Law & $(\mathrm{A} * \mathrm{~B}) * \mathrm{C}=\mathrm{A} *(\mathrm{~B} * \mathrm{C})$ & $(8)$ \\
& $\mathrm{A} *(\mathrm{~B}+\mathrm{C})=\mathrm{A} * \mathrm{~B}+\mathrm{A} \cdot \mathrm{C}$ & $(9)$ \\
& $\mathrm{A}+(\mathrm{B}+\mathrm{C})=(\mathrm{A}+\mathrm{B}) *(\mathrm{~A}+\mathrm{C})$ & $(10)$ \\
\hline Negation Law & $\left(\mathrm{A}^{\prime}\right)=\mathrm{A}$ & $(11)$ \\
& $\left(\mathrm{A}^{\prime}\right)=\mathrm{A}$ & $(12)$ \\
& $\mathrm{A}+\mathrm{A} \cdot \mathrm{B}=\mathrm{A}$ & $(13)$ \\
\hline Absortion law & $\mathrm{A} *(\mathrm{~A}+\mathrm{B})=\mathrm{A}$ & $(14)$ \\
& $\mathrm{A}+\mathrm{A}=\mathrm{A}$ & $(15)$ \\
& $\mathrm{A} * \mathrm{~A}=\mathrm{A}$ & $(16)$ \\
& $0+\mathrm{A}=\mathrm{A}---1^{*} \mathrm{~A}=\mathrm{A}$ & $(18)$ \\
& $1+\mathrm{A}=1---0 * \mathrm{~A}=0$ & $(19)$ \\
\hline
\end{tabular}




\begin{tabular}{|l|l|r|}
\hline & $\mathrm{A}+\mathrm{A}^{*} \mathrm{~B}-\mathrm{A}+\mathrm{B}$ & $(20)$ \\
& $\mathrm{A} *(\mathrm{~A}+\mathrm{B})=\mathrm{A} * \mathrm{~B}$ & $(21)$ \\
\hline De Morgan's & $(\mathrm{A}+\mathrm{B})^{\prime}=\mathrm{A}^{\prime} * \mathrm{~B}^{\prime}$ & $(22)$ \\
& $(\mathrm{A} * \mathrm{~B})^{\prime}=\mathrm{A}^{\prime}+\mathrm{B}^{\prime}$ & $(23)$ \\
\hline
\end{tabular}

Source: Own study.

Based on the rules in the Boolean theorem then the reduction process used to select the attributes the condition will take to generate rule of knowledge. The Reduction result obtained from the Discernibility Matrix process as present on Table 8 bellow:

Table 8. Reduction

\begin{tabular}{|c|l|c|l|}
\hline Class & CNF of Boolean Function & $\begin{array}{c}\text { Prime } \\
\text { Implication }\end{array}$ & Reduction \\
\hline $\mathrm{EC} 1$ & $(\mathrm{~B}+\mathrm{D}) * \mathrm{D} * \mathrm{~A}$ & $(\mathrm{~A} * \mathrm{D})$ & $\{\mathrm{A}, \mathrm{D}\}$ \\
\hline $\mathrm{EC} 2$ & $(\mathrm{~B}+\mathrm{D}) * \mathrm{~B} *(\mathrm{~A}+\mathrm{B}+\mathrm{D})$ & $\mathrm{B}$ & $\{\mathrm{B}\}$ \\
\hline $\mathrm{EC} 3$ & $\mathrm{D} * \mathrm{~B}(\mathrm{~A}+\mathrm{D})$ & $(\mathrm{B} * \mathrm{D})$ & $\{\mathrm{B}, \mathrm{D}\}$ \\
\hline $\mathrm{EC} 4$ & $\mathrm{~A} *(\mathrm{~A}+\mathrm{B}+\mathrm{D}) *(\mathrm{~A}+\mathrm{D})$ & $\mathrm{A}$ & $\{\mathrm{A}\}$ \\
\hline
\end{tabular}

Source: Own study.

Description:
$\{\mathrm{A}\}=$ Confidence
$\{\mathrm{D}\}=$ Passion $\{\mathrm{AD}\}=$ Confidence Passion
$\{B\}=$ Integrity
$\{\mathrm{BD}\}=$ Integrity, Passion

Once the result obtained from Reduction, the final step determines its General Rules. The resulting General Rules consist of the following combinations of attributes:

Reduction $\mathrm{A}=$ Confidence

- If Confidence $=$ good Then Customer Satisfaction is very satisfied OR Customer Satisfaction quite satisfied.

- If Confidence = simply Then Customer Satisfaction quite satisfied OR Customer Satisfaction very satisfied

Reduction B = Integrity

- If Integrity = High Then Customer Satisfaction is very satisfied OR Customer Satisfaction quite satisfied

- If Integrity = Low Then Customer Satisfaction quite satisfied

Reduction D = Passion

- If Passion = High Then Customer Satisfaction is very satisfied OR Customer Satisfaction quite satisfied

- If Passion = Low Then Customer Satisfaction quite satisfied

Reduction $\mathrm{AD}=$ Confidence, Passion

- If Confidence $=$ good And Passion $=$ high Then Customer Satisfaction is very satisfied OR Customer Satisfaction quite satisfied 
- If Confidence = enough And Passion = high Then Customer Satisfaction quite satisfied OR Customer Satisfaction very satisfied

- If Confidence $=$ enough And Passion $=$ low Then Customer Satisfaction quite satisfied

\section{Discussion}

As mentioned in the customer satisfaction theory on services are influenced by product quality, service quality, emotion, price, and cost. The valuation attribute on the customer satisfaction level used in this study refers to the emotional approach. Emotions believed to be one variable-forming customer satisfaction. When consumers make purchasing decisions, they are an emotional element, alongside their racial elements. Especially for certain products. Customer satisfaction is an emotional response, when consumers want to buy a product, certainly decide through a series of rational and emotional evaluations (Sanny et al., 2020; Ali et al., 2016; Calvo-Porral, Ruiz-Vega, and Lévy-Mangin, 2018; Hadiansah, 2017; Wang and Chou, 2013).

The rational aspect usually related to the basic functions of a product plus an attribute that complements the basic functions. While the emotional aspect will usually accompany the purchase decision when consumers meet with some additional attributes embedded in the product. This additional attribute can be a beautiful design, a compelling colour (or one that is fanatical with certain colours), the value of which is given by products, associations or images obtained if consuming, buying or using such products and other emotional factors (Santoso, 2018; Bakar, Damara, and Mansyur, 2020; Chen et al., 2020; Lee, Aziz, Sidin, and Saleh, 2014; Liu, Chi, and Gremler, 2019; Pedragosa, Biscaia, and Correia, 2015; Poushneh and VasquezParraga, 2019; Wong, 2004). The attribute of confidence, integrity, pride, and desire chosen to be the dimension of study in this research is a dimension in the emotional factor of a customer. While the satisfaction of the customers to be a decision and rough based on customer data information (Bakar et al., 2020).

The Rough Set approach has illustrated a series of knowledge information from attribute attributes within the customer to illustrate the degree of satisfaction it is felt. From the combination of knowledge generated through a series of previous experiments proved that the rough set can be used to dig the knowledge either manually or by using the application (Acharjya and Das, 2017; Chatterjee et al., 2018; Chen, 2009; Huang et al., 2016; Sembiring and Azhar, 2017). A description of the results in a set of rules on consumer satisfaction attributes identify some combination combinations of trust attributes with other attributes such as pride, integrity and desire. Although the end of result is that confidence dominates the rule.

\section{Concluding and Implications}

One of the goals of knowledge discovery is to extract meaningful information from raw data. Given the customer satisfaction in the past and present, along with loyalty behaviour. Best predictors of future customer retention. With a better understanding 
of customer perception, the company can determine the right action to meet customers ' needs. However, there can be ambiguity in customer data, which requires the need to analyse large amounts of subjective gratification data effectively. In this study, the theory of Rough Set has been applied to find the relationship between the attributes of confidence, integrity, pride, desire, and customer satisfaction of the service users of a flower-arranging company in Bungo district. The result of Rough Set approach from decision-making, core and reduction regulations that give us Valuable information to classify attributes. Only use core attributes quality classification reaches up to 0.77 . This implies that the core attribute is well chosen.

To properly estimate the classification. Based on this decision rule, confidence becomes the most dominant attribute. The results showed that the four dimensions of the emotional bond used as an attribute in the Rough Set process to analyse the level of customer satisfaction that strongly affects is the dimension of Confidence, this is evident from the resulting General Rule. Every decision produced always uses the confidence dimension in the comparison input, meaning the level of customer confidence in the company should be a special concern. In the dimensions of the emotional bonds the first dimensions are constructed and fundamental is the confidence dimension, this dimension indicates the level of customer confidence in the company. Confidence dimensions cannot stand itself yet to build long-term relationships with customers without by other dimensions.

The result of General Rule showed customer satisfaction (customer satisfaction level) average in the range is quite satisfied; therefore, the company must create a strategy in increasing customer satisfaction in the future. Previously, the company only use feedback directly from customers in the form of complaints as a material consideration in knowing the level of customer satisfaction (Al-malaise, 2013; Huang et al., 2016; Istrat and Lalić, 2017; Sembiring and Azhar, 2017).

\section{Limitations and Main Contributions}

A practical point of view, the use of a rough set has been able to elaborate on what is the problem in consumer satisfaction in the service sector so that the company has an opportunity to fix problems before real customers lose happen, namely the need for precautions should be done if the customer is dissatisfied and not loyal because the customer is considered as a valuable asset for the company.

In this study, a set of important attributes that assure high quality Classification and rules for each class the overall satisfaction presented. To companies that believe that these rules are with potentially valuable information to make better services. The results generated in this study opened up new avenues for customer satisfaction analysis. We must not limit the analysis of customer satisfaction survey data using conventional statistical methods. The Rough theory Set is an innovative tool for finding Knowledge of customer behaviour patterns. 
The limitation of these findings is that it is limited to the case study of one service company only. However, this approach can applied to the service sector with a welldesigned service satisfaction questionnaire by applying attributes and sample counts.

\section{References:}

Acharjya, D.P., Das, T.K. 2017. A framework for attribute selection in marketing using rough computing and formal concept analysis. IIMB Management Review, 29(2), 122-135. https://doi.org/10.1016/j.iimb.2017.05.002

Al-malaise, A.S. 2013. Implementation of A-priori Algorithm to Analyse Organization Data. Building Decision Support System, 66(9), 23-27.

Ali, F., Hussain, K., Omar, R. 2016. Diagnosing customers experience, emotions, and satisfaction in Malaysian resort hotels. European Journal of Tourism Research, 12, $25-40$

Alizadeh, A., Kianfar, F. 2013. Developing a model for citizens' satisfaction with public sector services based on rough sets theory: A case study of Tehran municipality. Tehnicki Vjesnik, 20(5), 795-802.

Bach, M.P., Ćurlin, T. 2020. Data mining approach to internal fraud in a project-based organization. IJSPM, 8(2), 81-101. https://doi.org/10.12821/ijispm080204.

Bakar, R.M., Damara, Z.F., Mansyur, A.Y. 2020. Post-service recovery emotion and customer trust: The role of satisfaction as mediation. Jurnal Manajemen Dan Pemasaran Jasa, 13(1), 17. https://doi.org/10.25105/jmpj.v13i1.5900.

Calvo-Porral, C., Ruiz-Vega, A., Lévy-Mangin, J.P. 2018. Does product involvement influence how emotions drive satisfaction? An approach through the Theory of Hedonic Asymmetry. European Research on Management and Business Economics, 24(3), 130-136. https://doi.org/10.1016/j.iedeen.2018.06.001.

Chatterjee, A., Mukherjee, S., Kar, S. 2018. A Rough Approximation of Fuzzy Soft SetBased Decision-Making Approach in Supplier Selection Problem A Rough Approximation of Fuzzy Soft Set-Based, 8658. https://doi.org/10.1080/16168658.2018.1517973.

Chen, T., Peng, L., Yin, X., Rong, J., Yang, J., Cong, G. 2020. Analysis of User Satisfaction with Online Education Platforms in China during the COVID-19 Pandemic. Healthcare, 8(3). https://doi.org/10.3390/healthcare8030200.

Chen, W.S. 2009. Analysis of a customer satisfaction survey using Rough Sets theory: A manufacturing case in Taiwan. Asia Pacific Journal of Marketing and Logistics, 21(1), 93-105. https://doi.org/10.1108/13555850910926263.

Dhandayudam, P., Krishnamurthi, I. 2013. Customer behavior analysis using rough set approach. Journal of Theoretical and Applied Electronic Commerce Research, 8(2), 21-33. https://doi.org/10.4067/S0718-18762013000200003.

Gholami, A., Sheikh, R., Mizani, N., Sana, S.S. 2018. ABC analysis of the customers using axiomatic design and incomplete rough set. RAIRO - Operations Research, 52(4), 1219-1232. https://doi.org/10.1051/ro/2018022.

Hadiansah, I. 2017. The Influence of Customer Perceived Value toward Customer Satisfaction. Jababeka Golf \& Country Club, 74-84.

Huang, C.C., Tseng, T.L., Chen, K.C. 2016. Novel Approach to Tourism Analysis with Multiple Outcome Capability Using Rough Set Theory. International Journal of Computational Intelligence Systems, 9(6), 1118-1132. https://doi.org/10.1080/18756891.2016.1256574. 
Istrat, V., Lalić, N. 2017. Association rules as a decision-making model in the textile industry. Fibres and Textiles in Eastern Europe, 25(4), 8-14. https://doi.org/10.5604/01.3001.0010.2302.

Jiang, H., Kwong, C.K., Law, M.C., Ip, W.H. 2013. Development of customer satisfaction models for affective design using rough set and ANFIS approaches. Procedia Computer Science, 22, 104-112. https://doi.org/10.1016/j.procs.2013.09.086.

Lee, S.Y., Aziz, Y.A., Sidin, S.M.D., Saleh, R. 2014. The influence of emotional labour strategies on customer satisfaction and word of mouth recommendations in group tours. International Journal of Economics and Management, 8, (Special issue), 8196.

Li, Y., Tang, J., Luo, X., Xu, J. 2009. An integrated method of rough set, Kano's model and AHP for rating customer requirements' final importance. Expert Systems with Applications, 36(3 PART 2), 7045-7053. https://doi.org/10.1016/j.eswa.2008.08.036.

Liou, J.J.H. 2009. A novel decision rules approach for customer relationship management of the airline market. Expert Systems with Applications, 36(3 PART 1), 4374-4381. https://doi.org/10.1016/j.eswa.2008.05.002.

Liou, J.J.H., Tzeng, G.H. 2010. A Dominance-based Rough Set Approach to customer behavior in the airline market. Information Sciences, 180(11), 2230-2238. https://doi.org/10.1016/j.ins.2010.01.025.

Liu, X.Y., Chi, N.W., Gremler, D.D. 2019. Emotion Cycles in Services: Emotional Contagion and Emotional Labor Effects. Journal of Service Research, 22(3), 285300. https://doi.org/10.1177/1094670519835309.

Morcov, S., Pintelon, L., Kusters, R. 2020. Definitions, characteristics, and measures of IT project complexity-a systematic literature review. International Journal of Information Systems and Project Management, 8(2), 5-21. https://doi.org/10.12821/ijispm080201.

Nafis, N.S.M., Makhtar, M., Awang, M.K., Rahman, M.N.A., Deris, M.M. 2016. Predictive modelling for telco customer churn using rough set theory. ARPN Journal of Engineering and Applied Sciences, 11(5), 3203-3207.

Omar, M., Syed-abdullah, S., Mohd, N. 2012. eTiPs: A Rule-based Team Performance. Prediction Model Prototype, 1, 390-394. https://doi.org/10.1016/j.protcy.2012.02.089.

Pedragosa, V., Biscaia, R., Correia, A. 2015. The role of emotions on consumers' satisfaction within the fitness context. Motriz. Revista de Educacao Fisica, 21(2), 116-124. https://doi.org/10.1590/S1980-65742015000200002.

Poushneh, A., Vasquez-Parraga, A.Z. 2019. Emotional Bonds with Technology: The Impact of Customer Readiness on Upgrade Intention, Brand Loyalty, and Affective Commitment through Mediation Impact of Customer Value. Journal of Theoretical and Applied Electronic Commerce Research, 14(2. https://doi.org/10.4067/s071818762019000200108.

Salajegheh, S. 2016. Measuring Levels of Customer Satisfaction using Rough Set Theory. International Journal of Humanities and Cultural Studies ISSN 2356-5926, 279295.

Sanny, L., Susastra, A.C., Roberts, C., Yusramdaleni, R. 2020. The analysis of customer satisfaction factors which influence chatbot acceptance in Indonesia. Management Science Letters, 10(6), 1225-1232. https://doi.org/10.5267/j.msl.2019.11.036.

Santoso, A.L. 2018. Journal of Management and Marketing Review Emotional Intelligence and Job Performance of Accounting Students Undertaking Internships. J. Mgt. Mkt. 
Review, 3(1), 40-47. Retrieved from:

www.gatrenterprise.com/GATRJournals/index.html.

Schoemaker, P.J.H., Day, G.S., Rao, G. 2020. Converting strategic ambiguity to competitive advantage: How Philips Lighting solved the challenge of LED technology disruption. Strategy and Leadership, 48(2), 10-17. https://doi.org/10.1108/SL-122019-0189.

Sembiring, M.A., Azhar, Z. 2017). Factors Analysis and Profit Achievement for Trading Company By Using Rough Set Method. International Journal of Artificial Intelligence Research, 1(1), 16. https://doi.org/10.29099/ijair.v1i1.15.

Shyng, J.Y., Wang, F.K., Tzeng, G.H., Wu, K.S. 2007. Rough Set Theory in analysing the attributes of combination values for the insurance market. Expert Systems with Applications, 32(1), 56-64. https://doi.org/10.1016/j.eswa.2005.11.002.

Stefanowski, J. 1998. On rough set-based approaches to induction of decision rules. Rough Sets in Knowledge Discovery, 1(1), 500-529.

Suchacka, G., Chodak, G. 2017. Using association rules to assess purchase probability in online stores. Information Systems and E-Business Management, 15(3), 751-780. https://doi.org/10.1007/s10257-016-0329-4.

Sulaiman, S., Rahim, N.A.A., Pranolo, A. 2016. Generated rules for AIDS and e-learning classifier using rough set approach. International Journal of Advances in Intelligent Informatics, 2(2), 103122. https://doi.org/10.26555/ijain.v2i2.74.

Turčínek, P., Turčínkova, J. 2015. Exploring consumer behavior: Use of association rules. Acta Universitatis Agriculturae et Silviculturae Mendelianae Brunensis, 63(3), 1031-1042. https://doi.org/10.11118/actaun201563031031.

Wang, M.Y., Chou, M.J. 2013. Behind the mask: The impact of service quality on consumer satisfaction and loyalty intentions. Journal of Applied Sciences, Vol. 13, 348-353. https://doi.org/10.3923/jas.2013.348.353.

Wong, A. 2004. The role of emotional satisfaction in service encounters. Managing Service Quality: An International Journal, 14(5), 365-376. https://doi.org/10.1108/09604520410557976.

Yakut, I., Turkoglu, T., Yakut, F. 2015. Understanding Customer's Evaluations Through Mining Airline Reviews. International Journal of Data Mining \& Knowledge Management Process, 5(6), 01-11. https://doi.org/10.5121/ijdkp.2015.5601.

Zeng, K. 2016. Preference Mining Using Neighbourhood Rough Set Model on Two Universes. Computational Intelligence and Neuroscience. https://doi.org/10.1155/2016/6975458.

Zifu, F., Hong, S., Lihua, W. 2015. Research of the classification model based on dominance rough set approach for china emergency communication. Mathematical Problems in Engineering. https://doi.org/10.1155/2015/428218. 